\title{
Fintech Implementation on the Financial Performance of Rural Credit Banks
}

\author{
Eni Suharti and Tri Endi Ardiansyah \\ Faculty of Economic and Bussines, University Muhammadiyah Tangerang \\ Email address: \\ suharti_eni@yahoo.co.id
}

\begin{abstract}
This study aims to determine whether the enactment of BI regulation No.19 / 12 / PBI / 2017 by Financial Services Authority (OJK) in Indonesia has an impact on the performance of banks, especially rural banks (RCB). This's because RCB are still bound by OJK regulations in lending with a loan mechanism requirements that are quite burdensome customers. The population used in this study is the RCB in Banten Province that registered by OJK for 2014 - 2018, the sampling method used is non probability sampling, the data analysis technique uses Comparative Analysis with descriptive quantitative approach, with the help of eview .9. the results are that for the year prior to the enactment of Bank of Indonesia regulation No. 19/12 / PBI / 2017 the variable lending and capital raising has a significant negative effect on the quality of productive assets, while for the Funding variable has no effect.
\end{abstract}

Keywords: Landing, Funding, Capital Raising, Quality of Productive Assets.

\begin{abstract}
Abstrak: Penelitian ini bertujuan untuk mengetahui apakah diberlakukanya peraturan BI No.19/12/PBI/2017 oleh OJK di Indonesia memiliki dampak terhadap kinerja perbankan khususnya BPR hal ini di sebabkan BPR masih terikat dengan peraturan OJK dalam pemberian pinjaman dengan mekanisme persyaratan pengajuan kredit yang cukup memberatkan nasabah.Populasi yang digunakan dalam penelitian ini BPR di Propinsi Banten yang terdaftar di Otoritas jasa keuangan untuk tahun 2014 - 2018, ,metode pengambilan sampel yang digunakan adalah non probability sampling, tehnik analisis data menggunakan Analisis Komparatif dengan pendekatan kuantitatif deskriptif, dengan bantuan Eview .9. hasil dari penelitian ini untuk tahun sebelum di berlakukannya peraturan BI No. 19/12/PBI/2017 variabel lending dan capital raising memiliki pengaruh negative yang signifikan terhadap kualitas asset produktif, sedangkan untuk variabel Funding tidak berpengaruh,.
\end{abstract}

Kata Kunci: Landing, Funding, Capital Raising, Kualitas Asset produktif.

\section{INTRODUCTION}

The growth of information and communication technology (ICT) has penetrated into various of sectors in every aspect of life today, one of the most phenomenal is usage of information technology that implemented to financial service sector called Financial 
Technology (Fintech), innovation in technology-based financial services will certainly disrupt financial markets. traditional.(Navaretti et al., 2018; Nicoletti et al., 2017)

Fintech companies are experiencing an ever-increasing development in this digital era, this can be seen from the presentation of the ( IMF,2017) which reports that global investment in fintech companies has increased or increasing from US \$ 9 billion in 2010 to US $\$ 25$ billion in 2016 For Indonesia it self, BPS has reported that fintech transactions up to 2017 have reached 15 billion US dollars, while the increasing development of Fintech Companies certainly has an impact on companies or financial institutions that are still traditional, many financial institutions that have not implemented Fintech will experience disruption, especially banks (Alt et al., 2018; Chen et al., 2017). Indonesia has made a regulation on Fintech, namely regulation No. 19/12 / PBI / 2017 as well as the Financial Services Authority which has enacted OJK Regulation No. 13 / POJK02 / 2018 concerning Digital financial innovations in the financial services sector.

Fintech is not a banking company but the same operation as banking, namely conducting financial transactions such as payments, loans and funding, what distinguishes it from People's Credit Banks is that in Fintech people do not have to have an account if they want to get financial services, while at Rural Bank if people want to get services finance such as lending and funding must have an account first (Dialysa, 2019).

The advantage that is felt by the community in obtaining financing provided by Fintech companies (especially Lending, Funding and Capital raising) causes people to move to use the services of Fintech companies, this of course makes banking companies, especially Rural Credit Banks experience the impact of the existence of Fintech, (Lusardi \& Mitchell, 2014) the community that used to be come to the Rural Credit Bank with a guarantee to apply for a loan now there is no need to go to the Rural credit Bank only needing gadgets and downloading applications from home and it does not take long for the application to be approved and funds can be disbursed, even the ease of information and technology has also penetrated into remote villages and all levels of society thus affecting the performance of Rural Credit Banks, where Rural credit Banks are banks that are identical to banks that serve small communities in remote areas. This of course has a bad impact on rural banks in acquiring and retaining their customers.

The shift in public interest in financial services should certainly affect the income of the Rural Credit Bank, where one of the service products provided is that loans channeled by the Rural Credit Bank have decreased, Harahap et al (2017) stated that the impact of fintech on Bank Lending Channel is negative. The decrease in public interest in lending funds at Rural credit Banks will certainly have an impact on the quality of the productive assets of Rural Credit Banks because loans are one of the instruments used in measuring the quality of earning assets in addition to the placement of other funds with the public. A bank is declared healthy if the value of the quality of its earning assets is less than 5\% while the allowance for earning assets losses is more than $81 \%$ (HANDAYANI, 2019).

\section{THEORITICAL REVIEW}

Fintech. The Growth of Fintech in Indonesia is in line with technological developments characterized by the continued development of the use of cellular telephones (cellphones) and internet services (Affandi et al., 2016) Fintech is an applied of information technology in financial services, (Keneddy, 2017) said that Fintech is an entity that combines 
technology with features. financial services that have resulted in changes to the prevailing order in the financial market, while according to (Mc Kinsey, 2016) Fintech is a financial service that is delivered through digital infrastructure including cell phones and the internet with minimal use of cash and traditional bank branches, unlike (Kawai, 2016). which emphasizes fintech as a technology that enables innovation in financial services. fintech is a form of technology-based financial innovation that can produce new business models, applications, processes or products with material effects related to financial markets, institutions and financial service providers (Rasyid, 2019). The classification of the Fintech Industry according to (Dorfleitner, 2017) is divided into four segments, namely: Financing, Asset management, Payment (Payment) Other Fintech (other Fintech functions).

The Fintech industry is generally worked on by startup companies where the company conducts financial transactions digitally, Financial technology that is born by star up companies can be classified as follows: a) .Crowdfunding and $\mathrm{P} 2 \mathrm{P}$, are channeling funds to the community and allowing to provide loans to people who not yet reached by the banking industry. b) Market aggregator, is the Financial collection data and will be presented to users c) .Risk and Management of Investment, the product categorized in this case is the provision of online investment products and online insurance., d) Payment, settlement and clearing, An example of this system is the use of block chain or a distributed ledger for conducting fund transfers, electronic money and mobile payments. (Langley and Leyshon, 2017). P2P lending and crowdfunding is a financial marketplace platform that will bring together fund providers and those who need funds. Because it is done on an online platform, the funding process with $\mathrm{P} 2 \mathrm{P}$ lending and crowdfunding can be done easier and quicker than in conventional banks. P2P lending and crowdfunding in their activities will be supervised by the OJK (Financial Services Authority). In Indonesia, there are several examples of Fintech organizers in the P2P lending sector including: Modalku.com, Temanusaha.com, and others. Market aggregator which is a portal or platform that provides a variety of financial information in the form of financial tips, investments and credit cards to its users. From the various financial information provided by the platform in the Fintech of this category, it is hoped that users can get guidance and be able to make the right financial decisions. Some examples of platforms in this type of Fintech are Cekaja.com and Kreditgogo.com, RajaPremi.com and Asuransi88.com and others. Risk Management and Investment In this type of Fintech, the community or users who use it will be helped to carry out financial planning and also monitor financial conditions become easier. Not only this type of Fintech people will be assisted to get the most appropriate investment products but also the development of this type of Fintech, namely the combination of the banking system, investment and the P2P lending concept, forms a type of Fintech that focuses on increasing business capital (Capital Raising). To take advantage of this Fintech, users are generally required to download the application first through the Play Store or the Apps Store. After the application is installed, the user needs to fill in the required data on the Fintech management system. Examples of Fintech in this category include Bibit, Jurnal.id, Sleekr and others.Payment, Clearing, and Settlement, Fintech which is categorized into this category is in the form of payment gateway and ewallet. By utilizing a payment gateway service, people can choose the desired payment method. In Indonesia, several Fintech that focus on payment gateway units include: iPaymu.com, paytrend.com, etc. Meanwhile, for e-wallets, of course they are more familiar because people have often used them. As the name implies, this e-wallet or electronic wallet will provide storage services and financial transactions in electronic 
form. Examples of e-wallets in Indonesia include the BI National Clearing System (SKNBI), OVO, GoPay, Dana, Doku and others.

Rural Credit Bank Financial Performance. Rural Credit Bank is a financial services company that focuses on financial services for the category of Micro, Small and Medium Enterprises (MSMEs) (Ibor et al., 2017), which are generally located in rural areas or suburbs, but as is common for commercial banks, rural Credit Bank in its operations under supervise by the Financial Services Authority. (OJK).

There is differential between the balance sheet and income statement components between banking and non banking have cause be distinctiveness of ratio used in measure financial performance. (Kasmir, 2017) explains that to find out the financial performance, it is could saw through the financial report presented by bank periodically. This financial reports also simultaneously describes the bank performance in the that period. The bank financial ratios according to khasmir (2017: 217) consist of: Ratio of Bank Liquidity, Ratio of Bank Solvency and Ratio of Bank Profitability.

The Financial Services Authority in supervising rural banks will also look at the quality aspect of its quality Assets as measured by the Quality of Productive Asset Ratio (KAP) and the Earning Asset Loss Ratio (PPAP). Quality of productive Asset Ratio. According to ( Ali , 2013) is the ratio used to measure the placement of funds in the form of deposits or loans, securities, placement of funds with other banks, and participation in order to obtain optimal results. The ratio of allowance for earning assets losses (PPAP) is a ratio used to measure allowance for losses on earning assets losses.

Lending. Lending is an activity of channeling funds to the public (Akujuobi and Nwezeaku, 2015), (Kasmir, 2014) states that lending is an activity of allowing a person or organization the use of money under an agreement to pay it back latter - it is usually in form loan for specific purpose, such as : investment, working capital, commercial credit in banking companies and those used in lending activities come from customer funds collected or collected then distributed to borrowers, whereas in fintech companies it is known as P2P lending, where the funds channeled as loans come from investors, either individually or as a corporation, with benefits in the form of interest rates (Aveni et al., 2015).

Funding. funding is an action of fundraising from the public in the from of demand deposits, savings deposits and time deposits, however Rural Banks do not issue checks and demand deposits in other words, funding activities carried out by rural banks do not include current accounts (ERWIN et al., 2018). Different from funding activities carried out by Fintech companies, Funding in a Fintech company is called crowdfunding, which is a fundraising activity for a project or business by several people carried out through online platforms. In crowdfunding there are three parties who play a role in it, namely the Project owner, supporters and parties who provide the platform. (Nizar, 2017) distinguishes crowdfunding based on the form of rewards given to funders into several types, name is: reward base on crowdfunding, equity base on crowdfunding and loan base on crowdfunding.

Capital Raising. Capital Raising or often referred to as Capital Provision, is a step taken by companies to increase their capital, (Kasmir, 2014) states that in banking companies, the source of funds can come from funds that come from the bank itself. The wider community 
and funds sourced from other institutions. This source of funds can be used to increase the company's capital

Conceptual Framework. From the discussion of the background and theory above, the conceptual framework can be described as follows:

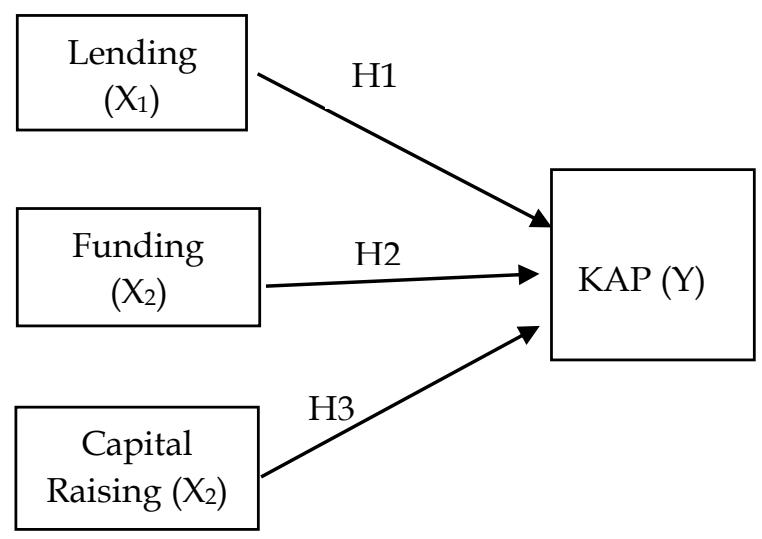

Figure 1. Conceptual Framework and Hypotheses of research

According to conceptual frame work above, hypothesis formulation could be drawn as follows:

Lending, P2P lending which held by Fintech companies makes it easy for people to get loans, this of course affects the distribution of funds to People's Credit Banks so that interest income that should be received as compensation will decrease, and will have an effect. on the quality of Productive assets as stated by (Harahap et al., 2017) states that the impact of Fintech on Bank Lending Channels is negative.

H1: Lending affects the quality of Productive assets.

The activities of Fundraising carried out by banking companies are generally in the form of demand deposit and time deposit where the collection of funds can only be done if the community is a customer at a bank, whereas in a Fintech company, fund raising can be done even though the community is not a customer (Biancone et al., 2019; Gomber et al., 2017). Fintech companies only provide platforms for customers to make it easier for people to invest. This convenience resulted in the transfer of Rural Credit Bank customers to Fintech companies and led to a decrease in funds entering the BPR. If the incoming funds decreased, of course it would have an impact on the decrease in the distribution of these funds to the public. Fintech Company offers the opportunities for household consumers and the business world, including small and medium enterprises (SMEs) to search financial services and offer convenience, speed of service (Nizar 2017).

H2: Funding affects the quality of productive assets. 
Capital Raising, the capital provided by rural banks comes from paid-up capital, to maintain the business continuity of the people's credit banks, the paid-up capital must be able to cover the amount of expenditure and there are funds available to support the liquidity of the rural credit bank (Awo \& Akotey, 2019). For this reason, the owner of a People's Credit Bank must have the ability to supply the additional fresh funds needed if in its operation it turns out that the Rural Bank is experiencing problems in its business, additional funds can actually be obtained from funds sourced from the wider community and funds sourced from other institutions besides funds. originating from the internal bank itself (EtuMenson \& Ato Enyamful, 2011). Banks that have sufficient capital will certainly be more able to distribute credit to the public, the greater the credit channeled, the greater the income received by the bank.

H3: Capital Raising affects the quality of Productive assets.

\section{METHODOLOGY}

Research Design, this research is quantitative in nature, namely research that uses data data in the form of numbers, quantitative methods can be interpreted as a research method based on the philosophy of positivism, used to research on a particular population or sample. Sugiyono (2016: 8).Measurement of Variables, the endogenous variable in this study is the Quality of Productive Assets that is measured by the formula:

$\mathrm{KAP}=\frac{\text { Clasisified of Produktive Assets }}{\text { Total productive Assets }} \times 100 \%$

While the exogenous variables in this study are Landing (X1), Funding (X2) and Capital Raising (X3), each of which is measured as follows:

Table 1. Measurement Variable

\begin{tabular}{l|l|c}
\hline Variable & \multicolumn{1}{|c}{ Measurement } & Scale \\
\hline Lending(X1) & Number of credits granted & Nominal \\
\hline Funding ( X2 ) & $\begin{array}{l}\text { Total Liabilities (time deposits } \\
\text { and savings) }\end{array}$ & Nominal \\
\hline Capital Raising ( X3 ) & Amount of increase in Capital & Precentage \\
\hline Source: Data Processing &
\end{tabular}

Sampling Method. The population in this study were rural credit banks in Banten province that were registered with the OJK and had reported their financial reports for 2014 - 2018 , namely as many as 58 banks, while the sampling technique used non-probability sampling techniques or saturated samples where all members population is used as a sample.

Method Of Collection Data. The secondary data used form of financial reports that have been published by OJK, in this study the data collection technique used is documentation. 
Data Analysis Method. During conducting this research, the method of data analysis by using data analysis model with quantitative descriptive analysis technique, quantitative descriptive analysis is carried out by analyzing a problem that is realized quantitatively and the results will be described descriptively. In this study, quantitative data analysis processed by calculating research data so as to produce the information required for the analysis. then the results of the research are explained and elaborated by considering and comparing the financial's performance of rural bank in Banten province before the enactment of Bank of Indonesia Regulation No.19 / 12 / PBI / 2017 concerning the Implementation of Fintech and after the enactment of the Bank of Indonesia Regulation.

\section{RESULT AND DISCUSSION}

The Result of Statistical tests, the objects in this research are Rural Banks in Banten Province which are registered with the Financial Services Authority of republic of Indonesia that have comprehensive financial reports in 2014 - 2018, there are 56 BPRs registered with OJK in 2014-2018. The BPR consists of Kab. Lebak 1 BPR, Kab.Pandeglang 2 BPR, Serang Regency 2 BPR, Tangerang Regency 23 BPR, Cilegon City 1 BPR, Tangerang City 19 BPR and South Tangerang City 7 BPR.

Descriptive Statistic Analysis, in this study descriptive statistical analysis is used to summarize information from the variables landing, funding, capital raising and quality of productive assets, at the time before and after the enactment of Bank Indonesia regulation No. 19/12 / PBI / 2017, the year of differentiation before enactment. is 2014 - 2016, while the year after implementation is 2017-2018. The measurements taken are to determine the mean, medium, and standard deviation

Table. 2. Result of Descriptive Statistic Test

\begin{tabular}{lcrrc}
\hline \hline & KAP & LENDING & FUNDING & $\begin{array}{c}\text { CAPITALRAI } \\
\text { SING }\end{array}$ \\
\hline \hline Mean & 0.078358 & 18.09772 & 30.57273 & 14.29758 \\
Median & 0.034000 & 11.70000 & 16.20000 & 8.900000 \\
Maximum & 0.602000 & 334.5000 & 798.8000 & 585.9000 \\
Minimum & 0.000000 & -284.4760 & -79.40000 & -486.5000 \\
Std. Dev. & 0.097862 & 52.53515 & 81.41273 & 97.89449 \\
Skewness & 2.348054 & 1.049895 & 5.831199 & 1.107628 \\
Kurtosis & 9.874585 & 18.57683 & 51.14483 & 19.13254 \\
& & & & \\
Jarque-Bera & 476.5293 & 1698.446 & 16870.81 & 1823.017 \\
Probability & 0.000000 & 0.000000 & 0.000000 & 0.000000 \\
Sum & 12.92900 & 2986.124 & 5044.500 & 2359.100 \\
Sum Sq. Dev. & 1.570612 & 452630.5 & 1086997. & 1571666. \\
& & & & \\
Observations & 165 & 165 & 165 & 165 \\
\hline
\end{tabular}

Source: Data Processing (2020) 
In the data for 2014 - 2016, the largest mean value was experienced by the Funding variable, which was 30.57273 , while KAP had the smallest mean value of 0.078358 . The highest median was experienced by the Funding variable, which was 16.20000 , while the KAP variable had the smallest median, which was 0.034000 . The largest standard deviation value experienced by the Capital Raising variable is 97.89449 , which means that the Capital Raising variable has a higher level of risk of experiencing changes compared to other variables. Meanwhile, the KAP variable has the lowest level of risk, which is 0.097862 . This shows that the KAP variable has experienced changes that do not fluctuate

Table. 3. Result of Descriptive Statistic Test

\begin{tabular}{lcccc}
\hline \hline & KAP & LENDING & FUNDING & $\begin{array}{c}\text { CAPITALRAI } \\
\text { SING }\end{array}$ \\
\hline \hline Mean & -3.260664 & 9.562838 & 9.692743 & 9.998619 \\
Median & -3.170369 & 10.01898 & 9.784105 & 9.844265 \\
Maximum & -0.918794 & 14.31695 & 14.51925 & 17.47553 \\
Minimum & -6.907755 & -2.302585 & -1.609438 & 2.747271 \\
Std. Dev. & 1.004711 & 2.572667 & 2.257993 & 1.677947 \\
Skewness & -0.885210 & -2.834187 & -2.716352 & 0.587615 \\
Kurtosis & 4.384010 & 13.21116 & 13.85346 & 9.103907 \\
& & & & \\
Jarque-Bera & 23.14523 & 625.1590 & 675.1798 & 177.0947 \\
Probability & 0.000009 & 0.000000 & 0.000000 & 0.000000 \\
Sum & & & & 1099.848 \\
Sum Sq. Dev. & 110.0294 & 721.4289 & 555.7402 & 306.8901 \\
Observations & 110 & 110 & 110 & 110 \\
\hline
\end{tabular}

Source: Data Processing (2020)

For data for 2017 - 2018, the largest mean value is experienced by the Capital Raising variable, which is 9,998619, while KAP has the smallest mean value of -3.260664 , the largest median is experienced by the Lending variable, which is 10.01898 , while the KAP variable has the smallest median of -3.170369 . The largest standard deviation value experienced by the Lending variable is 2.572667 , which means that the Lending variable has a higher level of risk of experiencing changes compared to other variables. Meanwhile, KAP variable has the lowest level of risk, which is 1.004711. This shows that the KAP variable has experienced changes that do not fluctuate.

Panel Data Regression Estimation. This test is used to choose which model will be implemented on data testing, in panel data regression's estimation there are three approach models such as the common effect's model, fixed effect model and random effect model, here are the results of each approach for the year 2014-2016 and 2017-2018 before and after to the enactment of Bank of Indonesia Regulation that concerning the Delivery of Fintech.

The following shows the results of the Chow - test, Hausman - test and langrange multiplier's test for 2014-2016 prior to the enactment of Bank of Indonesia Regulation concerning the implementation of Financial Technolog. 
Table 4. Chow test

Redundant Fixed Effects Tests

Equation: Untitled

Test cross-section fixed effects

\begin{tabular}{lrrr}
\hline \hline Effects Test & Statistic & d.f. & Prob. \\
\hline \hline Cross-section F & 4.215922 & $(54,107)$ & 0.0000 \\
Cross-section Chi-square & 188.147116 & 54 & 0.0000 \\
\hline \hline
\end{tabular}

Source: Data Processing (2020)

The above Table shows that the Cross-Section Probability for the year 2014-2016 a value is $0.0000<\alpha(0.05)$, then Ha is allowed. Thus the Fixed Effect's Model (FEM) is more proper to use in the Chow Test.

Table 5. Haustman Test

Correlated Random Effects - Hausman Test

Equation: Untitled

Test cross-section random effects

\begin{tabular}{lccc}
\hline \hline Test Summary & $\begin{array}{c}\text { Chi-Sq. } \\
\text { Statistic }\end{array}$ & Chi-Sq. d.f. & Prob. \\
\hline \hline Cross-section random & 5.428757 & 3 & 0.1430 \\
\hline \hline
\end{tabular}

Source: Data Processing (2020)

From the table above shows that the Cross-Section Random Probability for the year 2014-2016 value is $0.1430>(0.05)$, then H0 is accepted. Thus, the Random Effect's Model (REM) is more appropriate for the Hausman - Test.

Table 6. Lagrange Multiplier test

Lagrange Multiplier Tests for Random Effects

Null hypotheses: No effects

Alternative hypotheses: Two-sided (Breusch-Pagan) and one-sided

(all others) alternatives

\begin{tabular}{lccc}
\hline \hline & \multicolumn{3}{c}{ Test Hypothesis } \\
& Cross-section & Time & Both \\
\hline \hline Breusch-Pagan & 40.24419 & 0.915021 & 41.15921 \\
& $(0.0000)$ & $(0.3388)$ & $(0.0000)$
\end{tabular}

Source: Data Processing (2020)

The table above indicated that the Prob. The Breusch pagan cross section is 0.0000 $<\alpha(0.05)$ for the year 2014-2016 then Ha is accepted. Thus, the Random Effect's Model (REM) is more proper to use in the Langrage - Multiplier Test. 
From the three tests, it should be concluded that the Panel Data Regression Model that will be used in the Hypothesis Test and Panel Data Regression Equations is the Random Effect's Model (REM), because what is elected in the panel data regression model estimation is REM, so there is no need for classical assumption testing.

The following shows the results of the Chow - test, Hausman - test and langrange multiplier's test for 2017 - 2018 after the enactment of Bank of Indonesia Regulation concerning the implementation of Financial Technology.

Table 7. Chow test

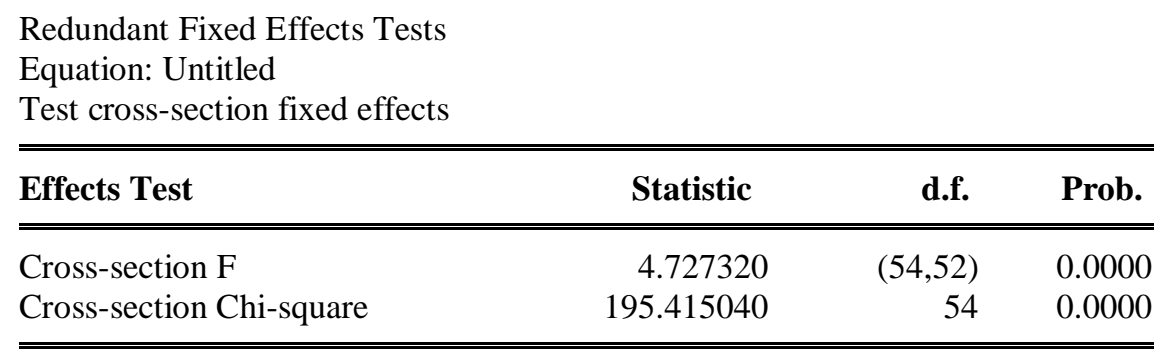

Source: Data Processing (2020)

The above Table shows that the Cross-Section Probability for the year 2017-2018 value is $0.0000<\alpha(0.05)$, then Ha is allowed. Thus the Fixed Effect's Model (FEM) is more proper to use in the Chow Test.

Table 8. Hausman Test

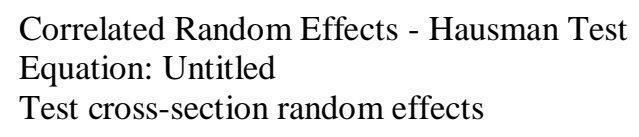

\begin{tabular}{lrrr}
\hline \hline Test Summary & $\begin{array}{r}\text { Chi-Sq. } \\
\text { Statistic }\end{array}$ & Chi-Sq. d.f. & Prob. \\
\hline \hline Cross-section random & 1.074042 & 3 & 0.7833 \\
\hline \hline
\end{tabular}

Source: Data Processing (2020)

From the table above shows that the Cross-Section Random Probability for the year 2017-2018 value is 0.7833> (0.05) then H0 is accepted. Thus, the Random Effect's Model (REM) is more appropriate for the Hausman - Test. 
Table. 9 Langrage Multiplier

Lagrange Multiplier Tests for Random Effects

Null hypotheses: No effects

Alternative hypotheses: Two-sided (Breusch-Pagan) and one-sided (all others) alternatives

\begin{tabular}{lcll}
\hline \hline & \multicolumn{3}{c}{ Test Hypothesis } \\
& Cross-section & Time & Both \\
\hline \hline Breusch-Pagan & $\begin{array}{l}23.36087 \\
(0.0000)\end{array}$ & $\begin{array}{l}0.204207 \\
(0.6513)\end{array}$ & $\begin{array}{l}23.56507 \\
(0.0000)\end{array}$
\end{tabular}

Source: Data Processing (2020)

The table above indicated that the Prob. The Breusch pagan cross section is 0.0000 $<\alpha(0.05)$ for the year 2017-2018, then Ha is accepted. Thus, the Random Effect's Model (REM) is more proper to use in the Langrage - Multiplier Test.

From the three tests, it should be concluded that the Panel Data Regression Model that will be used in the Hypothesis Test and Panel Data Regression Equations is the Random Effect's Model (REM), because what is elected in the panel data regression model estimation is REM, so there is no need for classical assumption testing.

Table 10. Result of Random Effect Model

\begin{tabular}{|c|c|c|c|c|}
\hline Variable & Coefficient & Std. Error & t-Statistic & Prob. \\
\hline $\mathrm{C}$ & 0.084774 & 0.010494 & 8.078211 & 0.0000 \\
\hline LENDING & -0.000368 & 0.000137 & -2.680702 & 0.0081 \\
\hline FUNDING & 0.000077 & $8.06 \mathrm{E}-05$ & 0.954982 & 0.3410 \\
\hline \multirow[t]{3}{*}{ CAPITALRAISING } & -0.000148 & $6.11 \mathrm{E}-05$ & -2.416106 & 0.0168 \\
\hline & \multirow{2}{*}{\multicolumn{2}{|c|}{ Effects Specification }} & & \\
\hline & & & S.D. & Rho \\
\hline \multirow{3}{*}{$\begin{array}{l}\text { Cross-section random } \\
\text { Idiosyncratic random }\end{array}$} & & & 0.065989 & 0.5118 \\
\hline & & & 0.064448 & 0.4882 \\
\hline & \multicolumn{2}{|c|}{ Weighted Statistics } & & \\
\hline R-squared & 0.106096 & Mean dependent var & & 0.038487 \\
\hline Adjusted R-squared & 0.089440 & S.D. dependent var & & 0.068046 \\
\hline S.E. of regression & 0.064932 & Sum squared resid & & 0.678806 \\
\hline F-statistic & 6.369622 & Durbin-Watson stat & & 2.367151 \\
\hline \multirow[t]{2}{*}{ Prob(F-statistic) } & 0.000417 & & & \\
\hline & \multicolumn{2}{|c|}{ Unweighted Statistics } & & \\
\hline R-squared & 0.104010 & Mean dependent var & & 0.078358 \\
\hline Sum squared resid & 1.407253 & Durbin-Watson stat & & 1.141824 \\
\hline
\end{tabular}

Source: Data Processing (2020) 
The coefficient of determination, from the Random Effect Model test for 2014-2016 before the enactment of BI regulation No.19 / 12 / PBI / 2017 is 0.089440 or $8.994 \%$, this proves that the variables Landing, Funding and Capital Raising can affect the variable of productive Asset Quality. 8,994\% and 91,006\% explained by other variables that were not researched. F-test, the results of the F-test (F test) of the random effect model for 2014-2016 before the BI regulation has a value of 6.369622 with prob (f Statistic) 0.00417 < from 0.05 means that the lending, funding and capital raising variables have an effect on the variable of earning asset quality.

T-test, the partial results of hypothesis testing from the random effect model for 20142016 before the enactment of this regulation the landing variable has a prob value of 0.0081 $<0.05$ in a negative direction, Funding 0.3410> 0.05 and Capital Raising 0.0166 with a negative direction, meaning that the landing and capital raising variables have a negative effect on the quality of productive assets while the funding variable has no effect.

Tabel 11. Result of Random Effect Model

\begin{tabular}{|c|c|c|c|c|}
\hline Variable & Coefficient & Std. Error & t-Statistic & Prob. \\
\hline $\mathrm{C}$ & -1.007109 & 0.642567 & -1.567321 & 0.1200 \\
\hline LENDING & -0.058255 & 0.029232 & -1.992835 & 0.0488 \\
\hline FUNDING & -0.051057 & 0.033558 & -1.521441 & 0.1311 \\
\hline CAPITALRAISING & -0.120175 & 0.051265 & -2.344209 & 0.0209 \\
\hline \multicolumn{5}{|c|}{ Effects Specification } \\
\hline & & & S.D. & Rho \\
\hline Cross-section random & & & 0.793408 & 0.6632 \\
\hline Idiosyncratic random & & & 0.565437 & 0.3368 \\
\hline \multicolumn{5}{|c|}{ Weighted Statistics } \\
\hline R-squared & 0.123600 & \multirow{5}{*}{\multicolumn{2}{|c|}{$\begin{array}{l}\text { Mean dependent var } \\
\text { S.D. dependent var } \\
\text { Sum squared resid } \\
\text { Durbin-Watson stat }\end{array}$}} & -1.467368 \\
\hline Adjusted R-squared & 0.098796 & & & 0.590189 \\
\hline S.E. of regression & 0.560277 & & & 33.27446 \\
\hline F-statistic & 4.983090 & & & 1.968474 \\
\hline Prob(F-statistic) & 0.002838 & & & \\
\hline \multicolumn{5}{|c|}{ Unweighted Statistics } \\
\hline R-squared & 0.103431 & \multirow{2}{*}{\multicolumn{2}{|c|}{$\begin{array}{l}\text { Mean dependent var } \\
\text { Durbin-Watson stat }\end{array}$}} & -3.260664 \\
\hline Sum squared resid & 98.64892 & & & 0.663970 \\
\hline
\end{tabular}

Source: Data Processing (2020)

For the results of the determination coefficient for 2017-2018 after the enactment of that regulation amounted to 0.098796 or $9.8796 \%$ and $90.1204 \%$ explained by Variables others that were not examined.

F-test, the results of the F-test (F test) of the random effect model for 2017-2018 after the enactment of BI regulation has a value of 4.983090 with Prob (F statistic) of 0.002838 
$<$ of 0.05 means that the landing, funding and capital raising variables affect the quality of earning assets. So that the panel data regression model is feasible to continue.

T-test, the partial results of hypothesis testing from the random effect model for 20172018 after BI regulation enactment, the landing variable has a value of $0.0488<0.05$ in a negative direction, funding $0.1311>0.05$ and capital raising $0.0209<0.05$, this proves that variable funding is not affect the quality of earning assets while landing and capital raising have a negative effect on the quality of productive assets.

\section{Study for Result of Research}

Impact of Landing to The Quality of earning assets. The result of research Landing variables have a negative effect on the quality of earning assets both before and after the implementation of BI Regulation No.19 / 12 / PBI / 2017, this means that if the landing has decreased, the value of the quality of earning assets will increase. This is in accordance with research conducted by Harahap at el (2017) which states that landing has a negative effect on the quality of earning assets.

Impact of Funding to The Quality of earning assets. The results of the test found that the Funding variable had no effect on the quality of earning assets both before and after the enactment of BI Regulation No.19 / 12 / PBI / 2017, This means that the impact of Fintech in the form of ease of obtaining funding is not utilized by customers and still trusts RCB as a means of saving funds in the form of deposits and savings. BI regulation No.19 / 12 / PBI / 2017 does not regulate any guarantee for deposits so that people trust RCB more as a place to invest.

Impact of Capital Raising to the Quality of earning assets. The results of the test show that the variable capital raising has a negative effect on the quality of earning assets both before and after the enactment of BI regulation No.19 / 12 / PBI / 2017, this means that if Capital Raising has decreased, the quality of earning assets will increase.

\section{CONCLUSION}

From the results of the research study, it can be concluded that: 1. Landing variables have a negative effect on the quality of Productive assets both before and after the implementation of BI Regulation No.19 / 12 / PBI / 2017. 2. Funding variables have no effect on the quality of earning assets both before and after the enactment of BI Regulation No.19 / 12 / PBI / 2017. 3. Capital raising variables have a negative effect on the quality of productive assets both before and after the enactment of BI Regulation No.19 / 12 / PBI / 2017 this indicates that the funds channeled to the public will generate bank income and provide benefits for Rural Credit Banks, the more funds distributed, the smaller the risk of productive asset quality for Rural Banks, as well as if the bank has sufficient capital. sufficient and able to support businesses such as channeling funds to the community, the People's Credit Bank can survive. The impact of the enactment of BI regulation No.19 / 12 / PBI / 2017 is on lending or channeling funds to the public because of the convenience provided by Fintech companies and on capital raising because Fintech companies do not have to have sufficient capital to channel funds to the public because funds that is distributed to the public from investors in Fintech companies, they only need to provide the platform. 
Implications. The Research Implication of this study is that although Fintech companies make it easy for people to access financial services, only lending is the community's choice. Because peer to peer lending offered by Fintech companies has an individual market share, Meanwhile for Financial Funding service, the public ( society) trusts the banking sector more because the money that been invested has been guaranteed by the deposit insurance corporation (Lembaga Penjamin Simpanan). On the contrary to Fintech which does not have a deposit insurance, so the risk of investing in Fintech tends to be higher, while capital raising in Fintech companies is automatically obtained by providing a platform for investors.

Limitations. This research has it's limitation as follow: the sample that been used only courage on rural bank on Banten Province so that can't describe the impact nationally, given the varied characteristics of the people in each region and there is still a minimum number of studies that are relevant to the variables studied.

Suggestion. To be able to maintain and increase credit distribution, it is better if rural credit banks must apply digital financial technology. Because if Rural credit banks are unable to keep up with external changes, especially in the field of technology, Rural credit banks will not be able to survive. In addition, Rural credit banks must also be able to innovate in creating convenience for their customers both in terms of applying for credit or in terms of credit installment payments.

\section{REFERENCE}

Affandi, Y, Harahap, BA, Bary, P. Kusuma, ACM, dan Rachman R.N. 2016. Dampak Financial Technology Pada Macro ekonomi dan Moneter. Laporan Hasil penelitian DKEM 2016

Ali, H. S. (2013). Pengelolaan BPR dan Lembaga Keuangan Pembiayaan Makro. Semarang

Alinda,Poppy Dwi,Hendra Kusuma. (2018). Analisis Kinerja Bank perkreditan Rakyat diwilayah malang raya, Jurnal Ilmu Ekonomi 2.3.

Akujuobi, A. B. C., and Nwezeaku, N. C. (2015). Bank lending activities and economic development in Nigeria; An empirical investigation. International Proceedings of Economics Development and Research, 85, 57.

Alt, R., Beck, R., and Smits, M. T. (2018). FinTech and the transformation of the financial industry. Springer.

Awo, J. P., and Akotey, J. O. (2019). The financial performance of rural banks in Ghana. World Journal of Entrepreneurship, Management and Sustainable Development.

Biancone, P. P., Secinaro, S., and Kamal, M. (2019). Crowdfunding and Fintech: Business model sharia compliant.

Basuki, Ferry Hendro, Hartiana Husein. (2019). Analisis SWOT Financial Technology pada Dunia Perbankan di kota Ambon, Jurnal Manis 2.1.

Bank Indonesia. (2017). Presentasi FinTech Office, Financial Technology:Perkembangan dan Respons Kebijakan Bank Indonesia, Jakarta.

Chen, Z., Li, Y., Wu, Y., and Luo, J. (2017). The transition from traditional banking to mobile internet finance: An organizational innovation perspective-a comparative study of Citibank and ICBC. Financial Innovation, 3(1), 1-16. 
Dialysa, F. (2019). Synchronize Fintech And The Banking Industry. International Journal of Advanced Research in Technology and Innovation, 1(2), 18-25.

Dortfleitner, G, Hornuf, L, Schmitt,M and Weber,M (2017). Fintech in Germany. Spring International Publishing AG.

Erwin, K., Abubakar, E., and Muda, I. (2018). The Relationship of Lending, Funding, Capital, Human Resource, Asset Liability Management to Non-Financial Sustainability of Rural Banks (BPRs) in Indonesia. Journal of Applied Economic Sciences, 13(2).

Etu-Menson, F., dan Ato Enyamful, D. (2011). Capital Structure and Profitability of Ghanaian Rural Banks-Case Studies of Kakum and Gomoa Ajumako Rural Banks in the Central Region of Ghana. Capital Structure and Profitability of Ghanaian Rural Banks-Case Studies of Kakum and Gomoa Ajumako Rural Banks in the Central Region of Ghana (September 20, 2011).

Gomber, P., Koch, J.-A., and Siering, M. (2017). Digital Finance and FinTech: Current research and future research directions. Journal of Business Economics, 87(5), 537580.

Handayani, R. (2019). Analysis Of Camel Method On Bank Health Level In Pt. Indonesia State Bank (Persero) TBK. International Management Journal January-June 2019, 84.

Harefa,Alvani Amaerita. (2018). Fianancial Technology, Regulasi dan Adaptasi perbankan di Indonesia, Fundamental Management Journal 3.1

Harahap, Berry.A., Bary Idham, Cinditya M.Kusuma, Nur Rakhman (2017), Perkembangan Financial Technology Terkait Central Bank Digital Currency (CBDC) terhadap Transmisi Kebijakan Moneter dan Makroekonomi, Working Paper Bank Indonesia.

Junger, Moritz,Mark Mietzner. (2019). Banking Goes to Digital: The adoption of Fintech Services by German Household, Finance Research Letter, Volume 34, http//doi.org/10.1016/j.frl.2019.08.08.

Kennedy, P.S.J. (2017). Literature Review: Tantangan terhadap Ancaman Disruptif dari Financial Technology dan peran pemerintah dalam menyikapinya, (2), 171 - 182.

Kawai, Yoshi. (2016). Fintech. International Association of insurance Supervisors (IAIS) Newsletter, May 2016.

Kasmir. (2014). Bank dan Lembaga Keuangan Lainnya. Jakarta: Rajawali Pers.

Kasmir. (2017). Analisis Laporan Keuangan. Jakarta: Rajawali Pers.

Ibor, B. I., Offiong, A. I., and Mendie, E. S. (2017). Financial inclusion and performance of micro, small and medium scale enterprises in Nigeria. International Journal of Research Granthaalayah, 5(3), 104-122.

Lusardi, A., and Mitchell, O. S. (2014). The economic importance of financial literacy: Theory and evidence. Journal of Economic Literature, 52(1), 5-44.

McKinsey \& Companny. (2016). Unlocking Indonesia's Digital Opportunity. October 2016.

Navaretti, G. B., Calzolari, G., Mansilla-Fernandez, J. M., \& Pozzolo, A. F. (2018). Fintech and Banking. Friends or Foes? Friends or Foes.

Nicoletti, B., Nicoletti, and Weis. (2017). Future of FinTech. Springer.

Nizar, Muhammad Aldi. (2017) Teknologi keuangan (Fintech): Konsep dan implementasinya di Indonesia, Warta Fiskal I Edisi\#5/2017, Kementerian Keuangan. 
Rasyid. A, Sekilas Perkembangan Fintech Di Indonesia, Business law, Faculty of humanities-Binus University (2019), from https://businesslaw.binus.ac.id/2019/03/19/sekilas-perkembangan-fintech-di-indonesia.

Thakor, Anjan.V. (2020). Fintech and Banking : What Do We Know, Journal of Financial Intermediation, Volume 41, doi.org/10.1016/j.jfi.2019.100833.

Wonglimpiyarat, Jerunee. (2020). Challenges and Dynamics of Fintech Crowdfunding : An Innovation System Approach Journal of High Technology Management Research ,Volume 29. Issue 2018. 